\title{
DOCUMENTS
}

Jaap Kloosterman

\author{
AN UNPUBLISHED LETTER OF \\ FILIPPO BUONARROTI TO CHARLES TESTE
}

Among a collection of miscellanea purchased by the International Institute of Social History in 1976 is an unexpected addition to the correspondence between Filippo Buonarroti and Charles Teste, ${ }^{1}$ a chief lieutenant of the Italian-French conspirator during his final years in Paris from 1830 to 1837. The letter is dated from Brussels, 23 October 1829, addressed to "Lemaire" $(\text { Teste) })^{2}$ and signed "Laurent" (Buonarroti), and was obviously written after the first meeting between the two men.

The moment was one of many interesting turning points in the career of Buonarroti, who had settled in Brussels after his expulsion from Switzerland in 1824, and who in 1828 had published his Conspiration pour l'Egalité dite de Babeuf. ${ }^{3}$ Whether or not it had been a "conscious contribu-

${ }^{1}$ Part of this correspondence was first published by $\mathrm{Ph}$. Robiquet in his Buonarroti et la secte des Egaux d'après des documents inédits (Paris 1910), an unsatisfactory edition since superseded by Armando Saitta's splendid Filippo Buonarroti: contributo alla storia della sua vita e del suo pensiero (Roma 1949; 2nd enlarged ed., Roma 1972, vol. II, pp. 73-85, 203-204, 212-218, 230-231). Alessandro Galante Garrone added considerably to the understanding of this "corrispondenza misteriosa, e in gran parte cifrata". Of both published and unpublished letters he noted: "Molte allusioni restano oscure, e molti pseudonimi indecifrabili. Conviene pertanto, allo stato attuale delle ricerche, astenersi da ipotesi troppo arrischiate, e ricavare dalla lettura probabile che se ne può ricavare senza abuso di congetture." (Filippo Buonarroti e $i$ rivoluzionari dell'Ottocento (1828-1837), Torino 1951; 2nd en-larged ed., Torino 1972, p. 60).

${ }_{2}^{2}$ Teste had an adopted son named Charles Lemaire; see Julien Kuypers, Les Egalitaires en Belgique: Buonarrotiet ses sociétés secrètes d'après des documents inédits 1824-1836 (Bruxelles 1960), p. 144.

${ }^{3}$ Conspiration pour l'Egalité dite de Babeuf, suivie du procès auquel elle donna lieu, et des pièces justificatives, etc., etc., 2 vols (Bruxelles: Librairie Romantique, 1828). References here are to the edition established by Robert Brécy and Albert Soboul, and prefaced by Georges Lefebvre, 2 vols (Paris 1957). 
tion to the mythology of the secret societies", ${ }^{4}$ this act of public propaganda strikingly coincided with the remodelling of the Sublimes Maîtres Parfaits first organized around 1810. This organization, now rebaptized Monde, was stripped of much Masonic ritual and enriched with four "grades d'observation" meant to facilitate the recruitment of people without introducing them into the inner mechanisms of the society. ${ }^{5}$ Clearly, such innovations, which have reminded scholars of Adolph von Knigge'sreorganization of the Bavarian Illuminati ${ }^{6}$ and which were later reinvented by Michail Bakunin, were well suited to enlarge the field of clandestine activities.

Probably this was just their purpose, for at least part of the explanation of Buonarroti's step may be found in the development in Great Britain and France of organizations that are known to have drawn his particular attention. In the Conspiration he took the defense of Robert Owen, whom he even ranked equal to Babeuf in all but his methods. ${ }^{7}$ And in his letters to Teste he proved keen on obtaining reliable information on Saint-Simonism, which was resurging after the burst of activity immediately following the death of its animator in 1825 had subsided, but which was still an "Ecole", not yet an "Eglise". ${ }^{8}$ Surely Buonarroti recognized both the opportunities and the dangers ${ }^{9}$ represented by movements that might well appeal to a proletarian following and whose programs were in many respects nearer to his own than any other had been for a very long time. The new Monde had been adapted to meet the challenge.

The man chosen by Buonarroti as a possible intermediary in his dealings with the Saint-Simonians was Charles-Antoine Teste (1782-1848), his junior by 21 years. ${ }^{10}$ Having occupied several mainly administrative posts under Bonaparte Teste had fled to Belgium after the Hundred Days. On his return to France in 1817 he started working in the book trade and around 1825 became co-owner of a Paris bookshop and publishing house, La Fôret.

4 J.M. Roberts, The Mythology of the Secret Societies (Frogmore, St Albans 1974), p. 356.

${ }^{5}$ On the Monde, see Saitta, I, ch. III; and II, pp. 133-167 (program document).

${ }^{6}$ Saitta rightly stressed the structural analogy as distinct from any historical influence (I, pp. 148-152). On the Illuminati, see now Manfred Agethen, Geheimbund und Utopie: Illuminaten, Freimaurer und deutsche Spätaufklärung (München 1984).

${ }^{7}$ Conspiration, pp. 212-215. See also Saitta, I, pp. 84-89.

${ }^{8}$ On Saint-Simonism in general Sébastien Charléty's often reprinted dissertation, Histoire $d u$ Saint-Simonisme 1825-1864 (Paris 1896), remains valuable. See also Jean Walch, Bibliographie du Saint-Simonisme (Paris 1967).

9 Not a few of his adherents, and not the least of them, eventually went over to SaintSimonism; see Galante Garrone, Filippo Buonarroti, pp. 408-416.

${ }^{10}$ Teste's biography is partly known through Félix Delhasse, see Kuypers, pp. 142-144. See also Dictionnaire biographique du mouvement ouvrier français, publ. sous la direction de Jean Maitron, vol. 3 (Paris 1966), pp. 438-439. 
By then he had turned republican. He may have joined Freemasonry, ${ }^{11}$ and took part in the underground Charbonnerie ${ }^{12}$ as well as in the legal Aidetoi, le Ciel t'aidera, the opposition's electoral society; but as Galante Garrone put it, up to 1829 Teste had probably not yet "una spiccata posizione nel mondo delle società segrete, e una accentuata personalità sul terreno ideologico". ${ }^{13}$

In 1828 he published a defense of Robespierre and the Jacobins by his close friend, Paul-Mathieu Laurent, ${ }^{14}$ who had been on the editorial board of le Producteur, the Saint-Simonian journal published in 1825-1826. Teste also knew the former Carbonaro, Saint-Amand Bazard, now the main spokesman of the Saint-Simonian group, and attended some of their conferences. ${ }^{15}$ It is hardly surprising, then, that he aroused the curiosity of Buonarroti, to whom he had already written in 1828 and who had checked on him through "ceux qui vous connoissent d'une manière particulière et parmi les quels il en est qui, par la justice qu'ils vous rendent, ont fait naître en moi le désir de vous offrir mes services dans ce pays". ${ }^{16}$ Teste was invited to Brussels in August 1829. He accepted and spent some time with Buonarroti in September or the first half of October. ${ }^{17}$

${ }^{11}$ In 1822 a Charles Teste was among the leaders of the Rite de Misraïm, a dissident high-grade masonic order shortly after dissolved by the police; see Arthur Lehning, From Buonarroti to Bakunin: studies in international socialism (Leiden 1970), p. 286. It may have been Charles-Antoine. His brothers, baron François-Antoine, a general of Bonaparte, and Jean-Baptiste, a future minister of Louis-Philippe, both were members, as was the Duc Decazes; see Pierre Chevallier, Histoire de la Franc-Maçonnerie française, II: la Maçonnerie missionnaire du libéralisme 1800-1877 (Paris 1974), p. 139.

12 Alan B. Spitzer, Old Hatreds and Young Hopes: the French Carbonari against the Bourbon Restoration (Cambridge, Mass. 1971), p. 309.

${ }^{13}$ Galante Garrone, Filippo Buonarroti, p. 16. - According to the Dictionnaire biographique (p. 438) Teste played a role in the founding of the republican newspaper La Tribune des Départements, which first appeared on 8 June 1829. But Georges Weill dates his involvement with the paper from the efforts to refound it after it ceased publication in October 1829; Teste failed to become gérant of the Tribune, which reappeared on 28 April 1830 under its former editors; see Histoire du Parti républicain en France 1814-1870 (Paris 1928), p. 19.

${ }^{14}$ Uraneit de Leuze [Laurent], Réfutation de l'Histoire de France de l'abbé de Montgaillard. After 1848 Laurent (1793-1877) was known as Laurent de l'Ardèche. On 20 August 1828 Buonarroti commented favorably on Laurent and his book in a letter to Emile Babeuf published by Maurice Dommanget, Sur Babeuf et la Conjuration des Egaux (Paris 1970), p. 376. - See also A. Galante Garrone, "I Sansimoniani e la storia della Rivoluzione francese", in: Rivista Storica Italiana, vol. LXI, 1949, pp. 351-378.

${ }^{15}$ Galante Garrone, Filippo Buonarroti, p. 17.

${ }^{16}$ Buonarroti to Teste, 6 August 1829; Saitta, II, p. 73. Buonarroti continued: "Je sais que monsieur Jacob et monsieur Charles, mes bons amis, vous ont entretenu de moi [. . .]." The noms de guerre have never been satisfactorily solved. Saitta's identification of Jacob with Voyer d'Argenson (I, p. 91) was rejected, on good grounds it seems, by Galante Garrone, Filippo Buonarroti, p. 61,89 .

${ }_{17}$ The invitation was contained in the letter of 6 August 1829. On 20 August Buonarroti told Teste he would be welcome "au plus tard à la moitié de septembre", urging him to advance the 
In his letters of invitation Buonarroti had announced that " $\mathrm{j}$ 'ai un ouvrage sur le quel je désire consulter un Libraire de votre mérite" and that "l'ouvrage [. . .] est de longue haleine". Although anything as ordinary as a new edition of the Conspiration or Buonarroti's efforts to obtain permission to return to France could have been discussed under that label ${ }^{18}$ Teste was no doubt introduced into the Monde and exhaustively interviewed on Saint-Simonism and its adherents. Apparently, he had brought with him some theoretical work on the creed - the main topic of the letter here published. Back home he arranged for another summary to be written by an unknown adept, which he sent to Brussels on 10 February 1830 and to which Buonarroti replied on 16 April in a long letter only partly preserved. ${ }^{19}$

The letter of 23 October 1829 contains Buonarroti's earliest known comments on some basic tenets of Saint-Simonism. As will be seen, he was definitely interested in its proposed economic system ("dans le quel l'homme jouiroit de tout le produit de son travail"), but raised major objections against its theory of progress. He doubts that the situation of the working classes has improved over the centuries..$^{20} \mathrm{He}$ disputes any claim based on a necessarily imperfect knowledge of a tiny fraction of the history of mankind. And, even more fundamentally, he dismisses the idea of gradual perfectibility from a moral point of view: if it were true, what scope would remain for social action? $?^{21}$

These statements are doubly interesting as they may be opportunely

date as much as possible and to stay several days (Saitta, II, p. 74). Teste was back in Paris on 17 October at the latest, when he wrote to Buonarroti as mentioned in our text.

${ }^{18}$ See Saitta, I, p. 92; Galante Garrone, Filippo Buonarroti, p. 63.

19 Published by Saitta, II, pp. 212-218. The text is analyzed in detail by Saitta, I, pp. 164-168; and by Galante Garrone, Filippo Buonarroti, pp. 40-49.

${ }^{20}$ In the letter of 16 April 1830 the argument is repeated as follows: "Est ce d'ailleurs un véritable progrès que la substitution du servage [. . . à l'esclavage proprément dit? Les serfs du régime féodal sont ils, réellement, plus heureux que les esclaves de l'antiquité et de l'islamisme? sous le rapport de la liberté il me semble que les uns n'ont pas beaucoup à envier aux autres, car si l'on voit dans nos vieilles croniques des serfs élevés aux dignités ecclésiastiques, on y voit aussi que les seigneurs se fesoient rendre ceux qui avoient obtenu la tonsure sans leur consentement. Il y a d'ailleurs une circonstance qui ne permet pas de faire pencher la balance plus d'un côté que de l'autre, et pas même en faveur de la condition de la plupart des manoeuvres salariés des temps modernes; la voici: le maître de l'esclave a beaucoup plus d'intérêt à conserver les forces de son esclave que le seigneur ou le propriétaire n'a d'intérêt à ménager celles du serf ou du salarié." (Saitta, II, p. 217).

${ }^{21}$ The letter of 16 April 1830 asks: "[. . . ] est il prouvé que depuis les tems connus le genre humain a constamment marché d'échelon en échelon vers la perfection? Grande question qui en embrasse beaucoup d'autres, et dont la solution dans un sens affirmatif pourroit présenter un côté nullement favorable aux intérêts futurs et réels de l'humanité; en effet à quoi bon chercher à améliorer par nos efforts l'état social puisque par une espèce de fatalité la société fait continuellement des progrès et doit, d'ordre divin, atteindre la perfection?" (Saitta, II, p. 215). 
compared to an argument Buonarroti put forward in defense of secret societies. In the program of the Monde he cited several historical examples of closely knit, ideologically united organizations and noted: "Dans la chute des institutions libres, dans la corruption générale des sentiments on ne pouvoit chercher un frein salutaire, une régénération future que dans un corps secret guidé par une autorité dictatoriale et pure; ce que les Jésuites firent pour tromper et asservir les hommes, le Monde a tenté de le faire dans la vue de les éclairer et de les délivrer." 22 In this view the Monde itself represented progress in a reactionary world; and part of the rationale for its hierarchy of grades was to lay the foundation of moral perfectibility through creating an officious education system: "A l'aide de la progression des doctrines et des devoirs on peut amener insensiblement aux principes de la [Société] des hommes, et surtout des jeunes gens qui ne demeurent dans les ténèbres que parce qu'ils n'ont pas eu l'occasion de s'instruire." ${ }^{23}$

It is tempting to set this conception beside the philosophy of history found in the Illuminati, whose leader Adam Weishaupt even saw the secret societies as the driving force in a cyclical development of world history, ${ }^{24}$ or in Bakunin, to whom a general idea of historical progress derived from Hegel and Comte (Saint-Simon's one-time secretary) was not incompatible with Ferdinand Lassalle's "iron law of wages", according to which capitalism was bound to plunge the workers in ever increasing misery. ${ }^{25}$ This is, however, part of a larger comparative study of secret societies, in which Buonarroti's letter to Teste would certainly serve as useful evidence.

Within a year after it was written the July Revolution in France greatly altered the circumstances in which Buonarroti had to operate. He returned to Paris and soon opened a new chapter in his conspiratorial activities by transforming the Monde into the Charbonnerie démocratique universelle. Teste, who had figured prominently in the Trois Glorieuses, published in 1833 a clearly buonarrotist Projet de constitution républicaine and at the end of that year was indicted (and acquitted) together with Marc-René Voyer d'Argenson as author of the Boutade d'un riche à sentimens populaires. $\mathrm{He}$ eventually came to be so thoroughly identified with the idea of communist conspiracy that a contemporary could classify Auguste Blanqui as having been raised at his school. ${ }^{26}$

\footnotetext{
22 Saitta, II, p. 161.

${ }^{23}$ Ibid., p. 139. "Société" is one of several possible readings for a colon inside a semicircle in the original manuscript.

${ }^{24}$ See Agethen, ch. IV.

${ }^{25}$ See notably L'Empire knouto-germanique et la révolution sociale, now in Archives Bakounine, vol. VII, ed. Arthur Lehning (Leiden 1981).

${ }^{26}$ Maurice Dommanget, "Buonarroti et Blanqui", in Babeuf et les problèmes du babouvisme (Paris 1963), p. 244.
} 
The letter is on the first two pages of a quarter of a quire of $23.8 \times 19 \mathrm{~cm}$. Lines have been drawn with a pencil on both pages in order to facilitate writing. The paper was folded in such a way that it could be sealed onto itself, producing a cover bearing the address ("A Monsieur Le Maire, Rue de la Sourdiere N: 5, à Paris") and two post stamps ("Brussel 23 Oct" and "Octobre 25 1829"). In the top left corner of the letter is pencilled: "64". In the top right corner an unknown hand has written: "Philippe Buonarrotti". A different hand, also unknown to me, has added: "condamné par la cour de vendome pour avoir le premier parlé de socialisme". One of these notes may be by Baudement, who took charge of Buonarroti's papers in 1837 .

The text was translated by Maryse Ornstein-Sportouch. In the original text spelling and interpunction have been retained. Words crossed out by Buonarroti are rendered between $<$. 


\section{The Original Text}

\section{Mon cher ami}

J'ai reçu ta lettre du 17 de ce mois et j'ai été charmé d'apprendre que tu es arrivé à Paris en bonne santé et sans aucun accident désagréable.

J'espère, mon bon ami, que cette lettre sera suivie de près de plusieurs autres par les quelles tu chercheras à effacer la peine que ton départ m'a causée, cela ne peut avoir lieu que par une longue suite de bonnes nouvelles soit sous le rapport de ta santé, soit sous celui de tes spéculations de commerce aux quelles je prends le plus vif intérêt.

Il est probable que tu auras déjà vû mon cher ami Jacob, à moins que tu ne l'aies trouvé à la campagne, rappelle moi à son souvenir et dis lui que j'attends de ses lettres.

A quoi en sont les Sainsimonistes? tu sais que je désire ardemment connoître à fond leur sistême, et à cet effet je te prie de ne pas oublier l'organisateur dont je n'ai que les quatre premiers numeros. La lecture plus attentive de l'ouvrage que tu m'as donné m'a mis un peu sur la voie. On y trouve les 〈traces〉 germes de l'opinion qui attribue à l'état moral du genre humain une marche progressive vers le bien, ainsi que quelques traits bien marqués du sistême économique dans le quel l'homme jouiroit de tout le produit de son travail. J'y ai vu aussi la classification des citoyens en savans, travailleurs, artistes et industriels et j'ai vu que c'est celle dont tu m'as parlé.

Quant à cette marche constante et progressive vers le bien il me semble voir le contraire dans ce que nous savons de l'antiquité et des tems plus rapprochés de nous; par exemple j'ai de la peine à croire que le peuple ait été plus heureux sous le régime féodal qu'aux beaux tems de la Grece et de Rome; je vois bien des esclaves dans ces Républiques, mais je vois aussi des serfs partout où la féodalité avoit jeté ses racines; or le maître avoit intérêt à la conservation de l'esclave, tandis que le seigneur ‘n'avait aucun > en avoit bien moins à celle du serf; et il n'est point vrai, comme le dit l'auteur de ce livre, qu'il fût aisé au serf de briser ses chaînes en se fesant clerc, car les anciens documents attestent que lorsque cela arrivoit le seigneur revendiquoit son serf et l'arrachoit à la jurisdiction ecclésiastique.

Il me semble aussi qu'il y a de la témérité à juger de la marche du Monde d'après un petit nombre de siecles dont nous connoisons inparfaitement l'histoire; le Monde est certainement plus vieux que ne le fait la genèse, et qui peut dire comment se sont passées les choses sur notre globe il y a 1000 ou 2000 siecles? Cette doctrine de la marche progressive peut être fort commode pour 〈justifier ceux > excuser les paresseux, mais je crains qu'au 
lieu de faire du bien elle ne mette des entraves aux travaux des hommes qui aiment à se rendre utiles à l'humanité. Au fond cette opinion est indifférente sous le rapport du mérite du systême ‘des $S$, économique des Sainsimonistes, et c'est surtout ce systême que je voudrois approfondir. Je voudrois aussi connoître au juste ce qu'il y a de vrai ou d'exagéré dans le misticisme qu'on leur attribue; tâche donc, mon cher ami, de me donner là dessus tous les éclaircissemens que tu pourras te procurer.

Je tiens, mon cher ami, pour un des jours les plus heureux de ma vie celui où j'ai eu le plaisir de t'embrasser, et j'espère que la continuation des sentimens que tu m'as témoignés, me fera éprouver de grandes jouissances et charmera ma vieillesse.

L'ami qui fit ta conduite t'embrasse ainsi que tous ceux que tu as vus chez moi.

Reçois mon cher ami l'accolade la plus tendre et la plus fraternelle de

Ton ami dévoué

Laurent

Bruxelles le 23 Octobre 1829. 


\section{The Translated Text}

\section{My dear friend}

I received your letter of the 17 th of this month, and was pleased to hear that you arrived in Paris in good health and with no unpleasant inconveniences.

I hope, my good friend, that your letter will be followed by many others, in which you will try to appease the despair which was caused by your departure. Only a steady stream of good news concerning your health or your affairs, ${ }^{27}$ in which I have the utmost interest, can ease my sorrow.

You will have probably met my dear friend Jacob, unless you have found him to be out in the country. Please give him my best regards and tell him that I look forward to his letters.

What is happening with the Saint-Simonians? You know that I desire very much to gain a perfect knowledge of their system, and for this purpose I beg you not to forget l'Organisateur, of which I have only the first four issues. ${ }^{28} \mathrm{~A}$ detailed reading of the book which you gave me has already provided me with some insight. One finds the «traces s seeds of the opinion which attributes to the moral state of humanity a progressive tendency towards improvement, as well as some marked traces of the economical system in which man can enjoy the whole product of his labour. I also noted the classification of citizens into scientists, workers, artists and industrials, ${ }^{29}$ and I noted that it is the classification you have mentioned.

As to this constant and progressive tendency towards improvement, I seem to recognize the contrary in what we know of ancient times and of more recent times. For instance, I find it difficult to believe that the masses have been happier under the feudal system than in the golden days of ancient Greece and Rome. True, there were slaves in these republics, but there were also serfs wherever the feudal system was rooted. Now, the master's interest lay in the preservation of the slave, whereas the feudal lord had (none) much less interest in the welfare of his serf; and it is not true, as the writer of the book claims, that it was easy for the serf to break his chains

\footnotetext{
${ }^{27}$ In the original: "tes spéculations de commerce". Although this might theoretically refer to business affairs it was quite common among nineteenth century conspirators to indicate in this way clandestine operations.

28 Publication of the Paris weekly l'Organisateur, a "journal des Progrès de la Science générale, avec un appendice sur les méthodes et les découvertes relatives à l'enseignement" according to the prospectus, had been announced in July 1829 by Laurent. The first issue appeared on August 15. - On 19 November Buonarroti repeated to Teste: "N'oublie pas l'organisateur et les détails que tu m'as promis." (Saitta, II, p. 74).

${ }^{29}$ In the original: "industriels", Saint-Simon's term.
} 
by becoming a clergyman, for the old documents reveal that whenever that happened the lord would reclaim his serf, and he would remove him from the ecclesiastic jurisdiction.

Also, it seems to me rather daring to judge the world by a limited number of centuries, whose history we know only imperfectly; the world is certainly older that it appears in Genesis, and who can tell how things were on our globe 1000 or 2000 centuries ago? This doctrine of a progressive tendency may be a convenient < justification > excuse for the lazy, but I am afraid that instead of bringing benefits, it will discourage works of men charitable to humanity. In fact this opinion is indifferent with regards to the economical merit of the system of the Saint-Simonians, and it is this system above all which I would like to study. I would also like to know what is correct or exaggerated in the mysticism attributed to them. Please, my dear friend, try to enlighten me on this matter as much as you possibly can.

My dear friend, I consider as one of the happiest days of my life the day when I had the pleasure of your kiss, and I hope my old age will be charmed by a continued rejoicing in the enticing feelings which you have shown me.

The friend who escorted you,$^{30}$ as well as those whom you have met at my home, send kisses.

The most tender and brotherly accolades, my dear friend, from

Your devoted friend,

Laurent

Brussels, 23rd of October 1829.

${ }^{30}$ No doubt "notre ami Henry qui t'accompagna à la voiture", as mentioned by Buonarroti to Teste on 22 February 1830 (Saitta, II, p. 78). Several names have been proposed to identify "Henry", of which Guglielmo Francinetti, suggested by Galante Garrone (Filippo Buonarro$t i, \mathrm{pp} .474-475$ ), seems the most plausible choice. 